\title{
Bacterial and Biodeterioration Analysis of the Waterlogged Wooden Lacquer Plates from the Nanhai No. 1 Shipwreck
}

\author{
Liuyu Yin ${ }^{1,+}\left(\mathbb{D}\right.$, Yin Jia ${ }^{1,+}{ }^{+}$, Mei Wang ${ }^{1}$, Huanhuan Yu ${ }^{1}$, Ying Jing ${ }^{1}$, Cuiting $\mathrm{Hu}^{1}$, \\ Fengyu Zhang ${ }^{1}$, Mingliang Sun ${ }^{1}$, Zijun Liu ${ }^{1}$, Yue Chen ${ }^{2}$, Jie Liu ${ }^{2}$ and Jiao Pan ${ }^{1, *}$ \\ 1 Key Laboratory of Molecular Microbiology and Technology of the Ministry of Education, Department of \\ Microbiology, College of Life Sciences, Nankai University, Tianjin 300071, China; nku_yly@163.com (L.Y.); \\ nkjy_2015@163.com (Y.J.); Mei_NK2019@163.com (M.W.); 1510837@email.nankai.edu.cn (H.Y.); \\ lynyingsky@163.com (Y.J.); hct20180725@126.com (C.H.); 13212002263@163.com (F.Z.); \\ 16602660537@163.com (M.S.); xxmuliuzijun@sian.cn (Z.L.) \\ 2 Chinese Academy of Cultural Heritage, Beijing 100029, China; chenyuepd@163.com (Y.C.); \\ heijicnyn@gmail.com (J.L.) \\ * Correspondence: panjiaonk@nankai.edu.cn; Tel.: +86-022-2350-5961 \\ + The two authors have the equal contribution to this work.
}

Received: 13 January 2019; Accepted: 4 February 2019; Published: 15 February 2019

Featured Application: Authors are encouraged to provide a concise description of the specific application or a potential application of the work. This section is not mandatory.

\begin{abstract}
To protect the lacquer plates from the Nanhai No. 1 shipwreck from being corroded by microorganisms, a series of studies were conducted on the four water-stored samples. The water samples were collected from the vessel where the lacquerware was stored in June and December 2017. In our study, high-throughput sequencing was conducted to reveal predominant bacterial communities. Then, three different media were used to isolate the dominant bacteria, and the $16 \mathrm{~S}$ rRNA genes were sequenced. Next, we tested the degradation activity of lignin and cellulose by the isolated bacterial strains. After being cultured on a medium containing carboxylmethylcellulose (CMC), almost all the isolated strains (except Microbacterium sp. NK-NH4, Ochrobactrum sp. NK-NH9, and Bacillus megaterium NK-NH10) showed the capacity for cellulose degradation. In addition, the lignin peroxidase (Lip) and laccase activity of the strains were shown by culturing the strains on one medium with azure and on another medium with Remazol brilliant blue. The results indicated that the Lip activity of all the strains was low, whereas the laccase activity of Microbacterium sp. NK-NH4, Bacillus tequilensis NK-NH5, Bacillus subtilis NK-NH6, Bacillus megaterium NK-NH10, and Bacillus velezensis NK-NH11 was relatively high. Finally, we tested the bacteriostatic efficacy of four biocides-Preventol ${ }^{\circledR}$ D7, BIT 20N, P91, and Euxyl ${ }^{\circledR}$ K100. We found that most strains were sensitive to D7 and 20N, while K100 had almost no impact.
\end{abstract}

Keywords: Nanhai No. 1 shipwreck; lacquerware; high-throughput sequencing; ligninolytic enzymatic activity; cellulolytic enzymatic activity; biocide effectiveness; bacterial diversity

\section{Introduction}

Nanhai No. 1 was a ship that carried a large amount of treasure for ocean-going trade along the Marine Silk Road [1]. It sank off the coast during the Southern Song Dynasty (1127-1279 AD) and had been resting at the bottom of the sea for decades until 2007. The discovery of the Nanhai 
No. 1 shipwreck is an unprecedented achievement and a historical landmark for Chinese underwater archaeology [2].

In recent years, several lacquer plates and many other archaeological woods have been excavated, raised, and conserved. For instance, in 1904, a site at Oseberg was excavated and conserved in Vestfold, Norway, along with a collection of wooden objects. Subsequently, the wood became powder, in the worst cases [3]. In China, a polychrome lacquer plate was excavated from a burial site and was stored in the Museum of Qin Shihuang Terracotta Horses and Warriors in Xi'an, Shanxi province, China. As a result of age, the wooden padding of the polychrome lacquer plate has completely decayed, while the paint film is completely fixed on the soil. Luckily, the shape of the lacquer plate remains intact, and the color of the painting is still bright [4]. Moreover, in March 2006, a lacquer plate was excavated from Tomb No. 10 (YLM10) of Yizheng, an important Early Han cemetery located in Yangzhou, Jiangsu province, China. Although YLM10 was badly damaged by the local brick factory, only one piece of the lacquered wooden plate was in good condition [5]. However, more than one hundred lacquer plates excavated from Tomb No. 1 of Fengpeng Ridge cemetery, located in Changsha, Hunan province, China, are in danger. Most of these plates were seriously distorted and badly mutilated when they were discovered in March 2006 [6].

Archaeological wood discovered in archaeological sites is a valuable archaeological find and tells us a lot about history; however, archaeological wood findings are rare because of long-term, microbiological biodegradation and unavoidable interactions with the environment [7]. Luckily, many scientists and archaeologists have been paying close attention to protecting archaeological wood.

Most of the objects from the Oseberg ship were treated with alum $\left(\mathrm{KAl}\left(\mathrm{SO}_{4}\right)_{2} \cdot 12 \mathrm{H}_{2} \mathrm{O}\right)$ to maintain the structural integrity of the wood. However, the release of sulfuric acid has reduced these artifacts to their current, mechanically weakened state, and, at present, the wood is highly acidic $(\mathrm{pH} \leq 2)$. Previous analyses have revealed that the carbohydrate component of the wood is almost completely absent [3]. What is the condition of wood found at other archaeological sites? In the Mausoleum of the First Qin Emperor, where the polychrome lacquer plate was excavated, the destruction of archaeological wood has been extremely rapid because environmental factors, such as ambient humidity, have changed a lot since the excavation. The lacquer plates along with the soil around them were covered with a film to retain the moisture, and PEG200 and PU emulsion were also used [4]. However, conditions were different for the lacquer plates excavated from Tomb No. 1 of Fengpeng Ridge cemetery. Due to its low moisture content and high mechanical strength, one of the lacquer plates was dried to keep it in its initial shape [6].

In addition to lacquer plates, many other wooden relics, such as bamboo slips, seem to face similar preservation challenges. The Jiandu Museum in Changsha, Hunan, houses a collection of bamboo slips belonging to the Three Kingdoms period-these slips were excavated in the Marco Pagoda. Due to the bamboo slips being buried underground for a long time before being unearthed, they were generally in a saturated state. A series of experiments have been conducted, and the results show that microorganisms contributed to much of the degradation of the bamboo slips [8]. In addition, another waterlogged archaeological wood called Xiaobaijiao No. 1 was salvaged from the seabed. The whole wooden ship suffered from biodegradation [9].

Generally, the protection process of waterlogged archaeological wood includes washing and desalting, sterilization, swelling, drying, padding, and painting $[6,10]$. Therefore, in our study, we are at the very first step of the whole process, and the lacquerware is stored in distilled water. Bacteria are still actively biodegrading the waterlogged archaeological wood, causing changes in the physical, chemical, and mechanical properties of the wood along with other environmental conditions (temperature, humidity, etc.) [11]. The environments suitable for wood preservation are waterlogged, extremely dry, or freezing, because microbial activity is drastically reduced under these conditions [7]. In this study, we aim to analyze the microbial degradation of the lacquerware under the condition of water saturation and hope to present some helpful protection measures. 


\section{Materials and Methods}

\subsection{Water Sample Collection}

The lacquerware from the Nanhai No. 1 shipwreck was kept in a refrigerator at $4{ }^{\circ} \mathrm{C}$. Some portions were stored in distilled water, and the remainder were covered by wet gauze.

Four water samples storing the lacquerware were used for the subsequent experiments. Sample No. 9 was collected from the distilled water storing the lacquer plate, named 2016NHIT0501(10935. Samples No. 10 and No. NHWS03 were from the water storing the lacquerware, named 2015NHIT0202(3):58. Sample No. NHWS04 was from the water storing the lacquerware, named 15C10 (1):0068. Samples No. 9 and No. 10 were collected in June 2017. Samples No. NHWS03 and No. NHWS04 were collected in December 2017. All the water samples were taken with $50 \mathrm{~mL}$ sterile centrifuge tubes held in ice baths and brought to the laboratory for analysis. (Shown in Figure S1)

\subsection{High-Throughput Sequencing}

DNA extraction of the collected water samples (No. 9, No. 10, No. NHWS03, and No. NHWS04) was performed using the PowerWater DNA Isolation kit (MO BIO Laboratories, Carlsbad, CA, United States), following the manufacturer's protocol. The total DNA was extracted from $300 \mathrm{~mL}$ of each water sample and dissolved in $100 \mu \mathrm{L}$ of the elution solution. After DNA extraction, the total DNA was sent to the Beijing Novogene Genome Sequencing Company and amplified by amplicon. As a result, the bacterial community contained in the water sample was analyzed. The raw sequencing data generated from this study were deposited into the National Center for Biotechnology Information (NCBI) Sequence Read Archive (SRA) under the accession numbers SAMN10147289-SAMN10147296 and SAMN10147297-SAMN10147304 for the bacterial reads in June and December 2017, respectively.

\subsection{Isolation of Dominant Bacteria}

Three different types of media were used to isolate the dominant bacteria from samples No. NHWS03 and No. NHWS04: (i) Luria Broth (LB) agar medium, (ii) MacConkey agar (MAC) medium, $20 \mathrm{~g}$ peptone, $5 \mathrm{~g}$ bile salt, $5 \mathrm{~g} \mathrm{NaCl}, 17 \mathrm{~g}$ agar, $10 \mathrm{~g}$ lactose, $10 \mathrm{~mL}$ crystal violet in aqueous solution $(0.01 \%), 5 \mathrm{~mL}$ neutral red in aqueous solution $(0.5 \%)$, and $1 \mathrm{~L}$ distilled water, and (iii) M2 agar medium, $5 \mathrm{~g} \mathrm{CH}_{3} \mathrm{COONa}, 0.5 \mathrm{~g}$ peptone, $0.5 \mathrm{~g}$ yeast extract, $0.5 \mathrm{~g}$ glucose, $0.5 \mathrm{~g}$ sucrose, $0.5 \mathrm{~g}$ soluble starch, $0.05 \mathrm{~g}$ trisodium citrate, $0.05 \mathrm{~g}$ malic acid, $0.05 \mathrm{~g}$ potassium sodium tartrate, $1 \mathrm{~g}$ $\mathrm{NH}_{4} \mathrm{NO}_{3}, 0.2 \mathrm{~g} \mathrm{NH}_{4} \mathrm{Cl}, 15 \mathrm{~g}$ agar, and $1 \mathrm{~L}$ distilled water $(\mathrm{pH}=7.6$ ) [12]. Each sample was spread onto these three different plates and incubated at $28^{\circ} \mathrm{C}$ with daily observation. The colonies with different morphologies and appearances were transferred to fresh plates to obtain pure isolates for DNA extraction and to study their physiological and chemical characteristics.

\subsection{DNA Extraction and Sequencing of the $16 \mathrm{~S}$ rRNA Gene}

The DNA extraction of pure strains isolated from the water samples was performed by the hexadecyltrimethylammonium bromide (CTAB) method [13]. The bacterial 16S rRNA genes were amplified using the 341f/907R primers. The primer sequences were 341f (CCTACGGGAGGCAGCAG) and 907R (CCCCGTCAATTCATTTGAGTTT). The PCR mixtures consisted of a total volume of $25 \mu \mathrm{L}$, containing $1 \mu \mathrm{L}$ of genomic DNA, $2.5 \mu \mathrm{L}$ of $10 \times$ reaction buffer, $2 \mu \mathrm{L}$ of $2.5 \mathrm{mM}$ deoxy-ribonucleoside triphosphate (dNTP) mix, $1 \mu \mathrm{L}$ of $10 \mu \mathrm{M}$ forward primer, $1 \mu \mathrm{L}$ of $10 \mu \mathrm{M}$ reverse primer, $0.3 \mu \mathrm{L}$ of $5 \mathrm{U} / \mu \mathrm{L}$ TransTaq-T DNA polymerase (TransGen Biotech, Beijing, China), and $\mathrm{ddH}_{2} \mathrm{O}$ to $25 \mu \mathrm{L}$. The PCR products were detected by electrophoresis in $1 \%$ agarose gels.

The PCR products were sequenced by GENEWIZ (GENEWIZ, Beijing, China). The sequences obtained were analyzed using the National Center for Biotechnology Information (NCBI) BLAST program (https:/ / blast.ncbi.nlm.nih.gov/Blast.cgi). Each isolate was compared against known taxa present in the GenBank database. 


\subsection{Determination of Ligninolytic Enzymatic Activity}

Ligninolytic enzymes are key enzymes that act in the degradation of lignin. Therefore, the higher the activity of strains producing laccase, manganese peroxidase, and lignin peroxidase, the stronger the ability of the given strains to degrade lignin.

Three different media were used to assess the ability of the isolates to degrade lignin: (i) sodium lignosulfonate agar medium, $0.2 \%$ sodium lignosulfonate, $2.0 \mathrm{~g}\left(\mathrm{NH}_{4}\right)_{2} \mathrm{SO}_{4}, 1.0 \mathrm{~g} \mathrm{~K}_{2} \mathrm{HPO}_{4}, 1.0 \mathrm{~g}$ $\mathrm{KH}_{2} \mathrm{PO}_{4}, 0.2 \mathrm{~g} \mathrm{MgSO}_{4}, 0.1 \mathrm{~g} \mathrm{CaCl}_{2}, 0.05 \mathrm{~g} \mathrm{FeSO}_{4}, 0.02 \mathrm{~g} \mathrm{MnSO}_{4}, 20.0 \mathrm{~g}$ agar, and $1 \mathrm{~L}$ tap water ( $\mathrm{pH}=7.0$ ), (ii) aniline blue agar medium, $10.0 \mathrm{~g}$ yeast extract, $20.0 \mathrm{~g}$ glucose, $20.0 \mathrm{~g}$ agar, $0.1 \mathrm{~g}$ aniline blue, and $1 \mathrm{~L}$ distilled water, and (iii) Remazol brilliant blue agar medium, $10.0 \mathrm{~g}$ yeast extract, $20.0 \mathrm{~g}$ glucose, $20.0 \mathrm{~g}$ agar, $0.1 \mathrm{~g}$ Remazol brilliant blue, and $1 \mathrm{~L}$ distilled water. All media were autoclaved for $20 \mathrm{~min}$ at $121^{\circ} \mathrm{C}$. The chemical structure of lignosulfonate is almost the same as that of natural lignin. Furthermore, the decolorization of aniline blue is related to the production of lignin peroxidase and manganese peroxidase but does not reflect the production of laccase produced by the strain, while laccase can decolor Remazol brilliant blue.

The screening of lignin-degrading bacteria was carried out in two steps. The bacteria were inoculated on sodium lignosulfonate agar plates using the streak plate method and incubated at $28^{\circ} \mathrm{C}$ for 5 days. Potential ligninolytic enzymes were initially obtained according to the colony growth conditions. Then, the bacteria were transferred onto Remazol brilliant blue agar plates and aniline blue agar plates and incubated at $28^{\circ} \mathrm{C}$ for 4 days. The lignocellulose degradation ability by the bacteria was directly proportional to the size of the decolorized circles. Furthermore, the larger the decolorized circles, the stronger the lignocellulose degrading ability [14].

\subsection{Determination of Cellulolytic Enzymatic Activity}

The cellulose degradation by bacteria was visualized on plates with cellulose as the sole carbon source and stained by Congo red. Congo red indicates the activity of cellulolytic enzymes-the dye can bind to the polysaccharide substrate of the medium and form transparent zones around the colony.

The purified colonies were separately transferred onto CMC-Na agar plates, which consisted of $15.0 \mathrm{~g}$ CMC-Na, $5.0 \mathrm{~g} \mathrm{NaCl}, 1.0 \mathrm{~g} \mathrm{KH}_{2} \mathrm{PO}_{4}, 0.2 \mathrm{~g} \mathrm{MgSO}_{4}, 10.0 \mathrm{~g}$ peptone, $5.0 \mathrm{~g}$ yeast extract, $18.0 \mathrm{~g}$ agar, and $1 \mathrm{~L}$ distilled water. All media were autoclaved for $20 \mathrm{~min}$ at $121^{\circ} \mathrm{C}$. Three plates were made for each strain and incubated at $28{ }^{\circ} \mathrm{C}$ for 4 days. After incubation, the media plates were flooded with $1 \mathrm{~g} / \mathrm{L}$ Congo red for 15-20 min. The dye was discarded, and the plates were flooded with $1 \mathrm{M}$ $\mathrm{NaCl}$ for $20 \mathrm{~min}$. Finally, the $\mathrm{NaCl}$ solution was discarded [15]. The diameters of the colonies and transparent circles were measured and termed D (diameter of colonies) and H (hydrolysis circle), respectively. The cellulolytic enzymatic activity of each bacterial colony was preliminarily determined according to the ratio of $\mathrm{H}$ and $\mathrm{D}$. Furthermore, the larger the $\mathrm{H} / \mathrm{D}$ value, the stronger the cellulose degrading ability.

\subsection{Determination of Biocide Effectiveness by Inhibition Assay}

The application of biocides is one of the most effective methods to control microbial deterioration. The selected biocides were Preventol ${ }^{\circledR}$ D7 (Lanxess, Köln, Germany), BIT 20N, P91, and Euxyl ${ }^{\circledR}$ K100 (Schülke, Norderstedt, Germany). All of these chemicals are isothiazolinone derivatives, which are considered broad-range biocides [16].

The purified single colonies were picked up with a sterile cotton swab and coated on LB agar plates. Filter paper was cut to make circles with a $0.7 \mathrm{~cm}$ diameter. Five pieces were put on each LB agar plate, four of which were loaded with $10 \mu \mathrm{L}$ of different biocides $(0.5 \%)$. The remaining piece was loaded with sterile water as a control. The plates were examined for clear zones after incubation at $28{ }^{\circ} \mathrm{C}$ for 3 days. Measuring the diameter of the clear zones indicated the effectiveness of the biocidal agents. Each antimicrobial agent test comprised three replicates. All materials (media, cotton swabs, etc.) were autoclaved for $20 \mathrm{~min}$ at $121^{\circ} \mathrm{C}$. 


\section{Results}

\subsection{Bacterial Community Analyses}

The diversity of the bacterial community was assessed using high-throughput sequencing on an Illumina HiSeq 2500 PE250 platform (Novogene Bioinformatics Technology Co., Ltd. Beijing, China) for the four stored water samples. Two of the samples were collected in June, and another two were collected in December 2017. The ten most-abundant genera are presented in Figure 1. The bacterial communities in the four water samples mostly consisted of Xanthobacter, Rhizobium, Acinetobacter, Variovorax, Flavobacterium, Pseudomonas, Neorhizobium, Fusibacter, Sphingobacterium, Brevundimonas, Geothrix, Novosphingobium, Sphingobium, Cupriavidus, Haliscomenobacter, Microbacterium, Ralstonia, Unidentified_Mitochondria, and others. Others were predominant in all four water samples, and the genera Flavobacterium and Pseudomonas were detected in all four samples. The most abundant identified genus of the two water samples collected in June was Xanthobacter, which accounted for $21.73 \%$ of the detected signatures with an average of $10.87 \%$ in the two samples. Rhizobium and Acinetobacter took the second and third place, accounting for $14.86 \%$ and $11.20 \%$ with an average of $7.43 \%$ and $5.60 \%$, respectively. Meanwhile, Xanthobacter represented the greatest bacterial proportion of sample No. 9, accounting for $18.46 \%$, and Acinetobacter was the primary genus in sample No. 10 , accounting for $3.74 \%$. Other major genera, including Variovorax and Flavobacterium, comprised bacterial signatures in the two water samples of $7.44 \%$ and $5.49 \%$, respectively. Flavobacterium was present in the greatest bacterial proportion of the identified genera in the two water samples collected in December, accounting for $16.60 \%$ with an average of $8.30 \%$. Pseudomonas and Novosphingobium followed in proportion, accounting for $7.21 \%$ and $6.87 \%$ with an average of $3.61 \%$ and $3.44 \%$, respectively. The dominant genera of the two water samples were Flavobacterium (No. NHWS03) and Novosphingobium (No. NHWS04), accounting for $12.81 \%$ and $5.24 \%$, respectively. In addition, Brevundimonas, Geothrix, Microbacterium, and Haliscomenobacter were other major members of the bacterial communities in the two samples, and they represented $6.00 \%, 5.35 \%, 5.31 \%$, and $4.70 \%$, respectively.

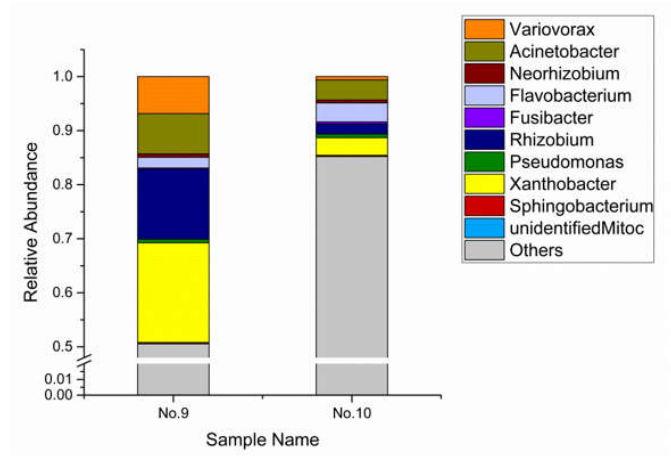

A

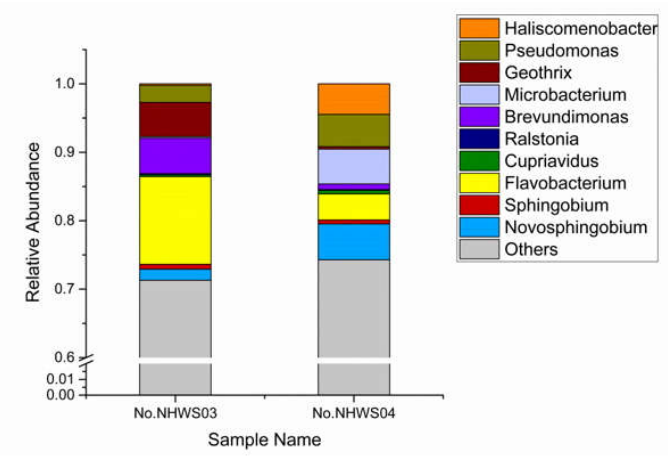

B

Figure 1. Relative abundance of the ten most-abundant microbial genera among the four samples. The relative abundance for each sample is shown as a percentage. Bacterial genera are colored according to the legend on the right. (A) Shows water samples No. 9 and No. 10 collected in June 2017, and (B) shows water samples No. NHWS03 and No. NHWS04 collected in December 2017.

The distribution of the bacterial communities in the two collections was different; however, the two samples collected at the same time had similar bacterial communities. Xanthobacter, Rhizobium, and Acinetobacter were the three most-abundant genera in the collection sampled in June, but these were not present in the top ten genera of the samples collected in December. In the same way, the genus Novosphingobium, the third largest member of the bacteria represented in the samples collected in December, was present as one of the ten most-abundant genera in June. The composition of other major bacterial communities was also quite different. 


\subsection{Isolation of Dominant Bacteria}

Two water samples were smeared on LB medium, M2 medium, and MacConkey agar (MAC) medium and incubated for 4-5 days. Then, different colonies were selected, purified, and isolated by cross lining on the LB medium. After DNA molecular identification, the isolated and pure strains were named Microbacterium sp. NK-NH4 (MH997669), Bacillus tequilensis NK-NH5 (MH997670), Bacillus subtilis NK-NH6 (MH997671), Pseudomonas sp. NK-NH7 (MH997672), Bacillus sp. NK-NH8 (MH997673), Ochrobactrum sp. NK-NH9 (MH997674), Bacillus megaterium NK-NH10 (MH997675), Bacillus velezensis NK-NH11 (MH997676), Microbacterium sp. NK-NH12 (MH997677), and Stenotrophomonas sp. NK-NH14 (MH997679). The results are presented in Table 1.

Table 1. Similarity in partial $16 \mathrm{~S}$ rDNA sequences of clones to sequences of their closest bacterial relatives available in the Genbank nucleotide sequence database.

\begin{tabular}{cccccc}
\hline \multicolumn{7}{c}{ Molecular Identification of Strains Isolated from the Water Samples } \\
\hline Bacteria & $\begin{array}{c}\text { Accession } \\
\text { Number }\end{array}$ & $\begin{array}{c}\text { Closet Relative } \\
\text { Strain }\end{array}$ & $\begin{array}{c}\text { Accession } \\
\text { Number }\end{array}$ & $\begin{array}{c}\text { Similarity } \\
\text { (\%) }\end{array}$ & Source \\
\hline NK-NH4 & MH997669 & Microbacterium sp. & DQ658916.1 & $99 \%$ & water samples \\
NK-NH5 & MH997670 & Bacillus tequilensis & MG519475.1 & $93 \%$ & water samples \\
NK-NH6 & MH997671 & Bacillus subtilis & KY510927.1 & $99 \%$ & water samples \\
NK-NH7 & MH997672 & Pseudomonas sp. & MF436694.1 & $99 \%$ & water samples \\
NK-NH8 & MH997673 & Bacillus sp. & MG827113.1 & $99 \%$ & water samples \\
NK-NH9 & MH997674 & Ochrobactrum sp. & MF442305.1 & $99 \%$ & water samples \\
NK-NH10 & MH997675 & Bacillus megaterium & MG818943.1 & $99 \%$ & water samples \\
NK-NH11 & MH997676 & Bacillus velezensis & MH014956.1 & $99 \%$ & water samples \\
NK-NH14 & MH997679 & Stenotrophomonas sp. & MH144251.1 & $99 \%$ & water samples \\
\hline
\end{tabular}

\subsection{Degradation of Cellulose and Lignin by Isolated Bacterial Strains}

All isolated strains were cultured on a medium containing carboxymethylcellulose (CMC) to determine whether they could degrade cellulose. These strains were cultured on CMC plates at $28^{\circ} \mathrm{C}$ for 4 days (Shown in Figure S2). As shown in Figure 2, after flooding the plates with Congo red for 15-20 min and eluting with $\mathrm{NaCl}$ solution for $20 \mathrm{~min}$, Microbacterium sp. NK-NH4, Ochrobactrum sp. NK-NH9, and Bacillus megaterium NK-NH10 barely grew and almost did not show degradation circles. The rest of the cultured bacteria showed different sizes of degradation circles. Bacillus tequilensis NK-NH5 and Bacillus velezensis NK-NH11 had the highest capacity for cellulose degradation (H/D > 3.0). Stenotrophomonas sp. NK-NH14 also showed a high capacity for cellulose degradation (H/D > 2.0). Bacillus subtilis NK-NH6, Pseudomonas sp. NK-NH7, and Bacillus sp. NK-NH8 had a relatively lower capacity for cellulose degradation $(\mathrm{H} / \mathrm{D}<2.0)$, even though these genera grew more vigorously on the plates. 


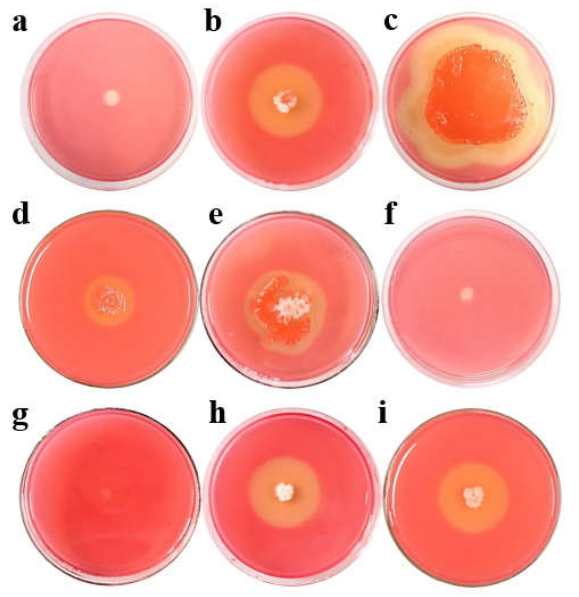

A

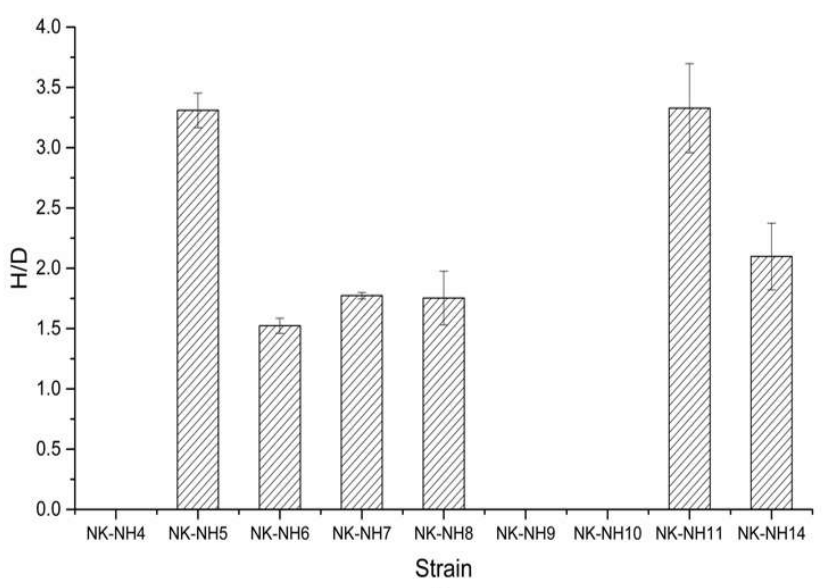

B

Figure 2. Photograph showing cellulolytic enzymatic activity of each bacterial colony. (A) The colonies of nine strains grown on carboxymethylcellulose (CMC) plates at $28^{\circ} \mathrm{C}$ for 4 days. Different transparent circles are shown after flooding with Congo red, indicating different degrees of cellulose degradation: (a) Microbacterium sp. NK-NH4, (b) Bacillus tequilensis NK-NH5, (c) Bacillus subtilis NK-NH6, (d) Pseudomonas sp. NK-NH7, (e) Bacillus sp. NK-NH8, (f) Ochrobactrum sp. NK-NH9, (g) Bacillus megaterium NK-NH10, (h) Bacillus velezensis NK-NH11, and (i) Stenotrophomonas sp. NK-NH14. (B) The diameters of the colonies and surrounding transparent circles on CMC plates were measured and expressed as $\mathrm{D}$ and $\mathrm{H}$, respectively. The cellulolytic enzymatic activity of each bacterial colony was preliminarily determined according to the ratio of $\mathrm{H}$ and $\mathrm{D}(\mathrm{H} / \mathrm{D})$.

Next, all strains isolated from the water samples collected in December 2017 were first cultured on a medium containing sodium lignosulfonate at $28^{\circ} \mathrm{C}$ for 5 days. All strains could grow colonies on the plates. Then, these strains were cultured on a medium with azure and Remazol brilliant blue at $28^{\circ} \mathrm{C}$ for 4 days. On the medium with azure, none of the strains presented clear and distinct degradation zones, indicating that they had little capacity to produce lignin peroxidase (LiP) and manganese peroxidase $(\mathrm{MnP})$. Among them, Microbacterium sp. NK-NH4 and Ochrobactrum sp. NK-NH9 barely grew.

As shown in Figure 3, on the medium with Remazol brilliant blue, Pseudomonas sp. NK-NH7, Bacillus sp. NK-NH8, Ochrobactrum sp. NK-NH9, and Stenotrophomonas sp. NK-NH14 did not show degradation zones. The rest of the cultured bacteria showed different sizes of decolorized circles, indicating that they had the ability to produce laccase; however, the enzyme production was weak $(\mathrm{H} / \mathrm{D}<2.0)$. Bacillus megaterium NK-NH10 had the most distinct degradation circle and presented a relatively high ability to produce laccase together with Microbacterium sp. NK-NH4. Bacillus tequilensis NK-NH5, Bacillus subtilis NK-NH6, and Bacillus velezensis NK-NH11 showed degradation zones; however, these zones were not clear, and the ratio of $\mathrm{H}$ and $\mathrm{D}$ was lower than 1.5. 


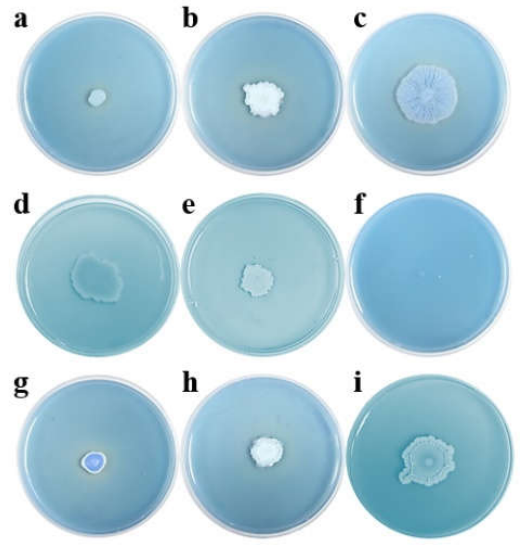

A

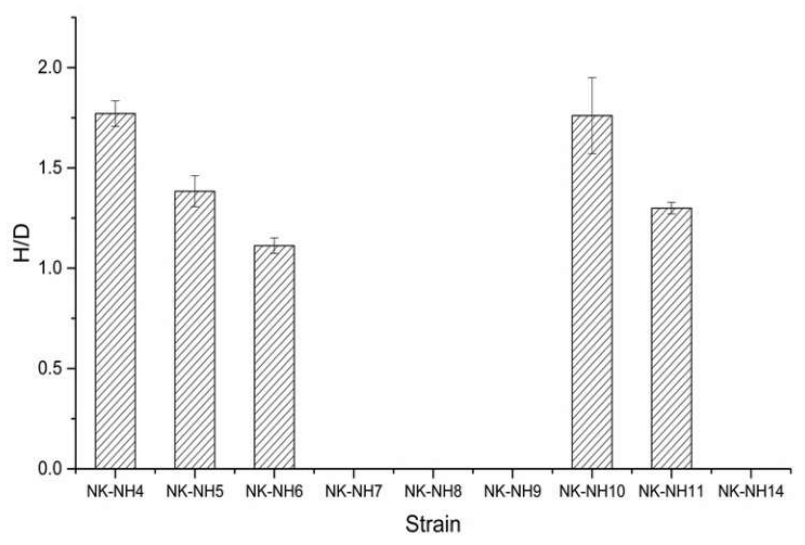

B

Figure 3. Photograph showing laccase activity of each bacterial colony. (A) Colonies of nine strains grown on Remazol brilliant blue plates at $28^{\circ} \mathrm{C}$ for 4 days: (a) Microbacterium sp. NK-NH4, (b) Bacillus tequilensis NK-NH5, (c) Bacillus subtilis NK-NH6, (d) Pseudomonas sp. NK-NH7, (e) Bacillus sp. NK-NH8, (f) Ochrobactrum sp. NK-NH9, (g) Bacillus megaterium NK-NH10, (h) Bacillus velezensis NK-NH11, and (i) Stenotrophomonas sp. NK-NH14. (B) The diameters of the colonies and surrounding transparent circles on Remazol brilliant blue plates were measured and expressed as D and $\mathrm{H}$, respectively. The ability of each bacterial colony to produce laccase was preliminarily determined according to the ratio of $\mathrm{H}$ and $\mathrm{D}(\mathrm{H} / \mathrm{D})$.

\subsection{Biocide Susceptibility}

To observe the susceptibility of the strains to biocides, we measured the strain growth by adding four kinds of biocides to LB plates. The drugs containing isothiazolinones included Preventol ${ }^{\circledR}$ D7, BIT 20N, P91, and Euxyl ${ }^{\circledR}$ K100, which can inhibit bacterial growth. All the isolated strains showed inhibition rings at a $0.5 \%$ concentration of biocide, indicating that the strains were all sensitive to isothiazolinones. However, the effects exerted by the different agents on bacterial growth suppression were different. Among the four agents, the efficacy of Euxyl ${ }^{\circledR}$ K100 was the smallest, while Preventol ${ }^{\circledR}$ D7 and BIT $20 \mathrm{~N}$ were the most effective. However, the efficacy of the individual agents varied with the various strains. The results are presented in Figure 4 and Table S1.

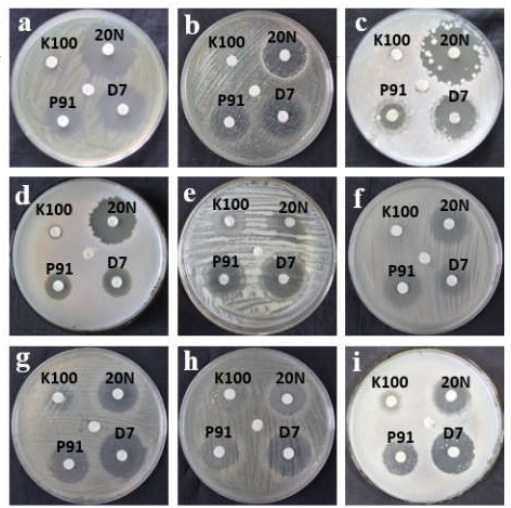

A

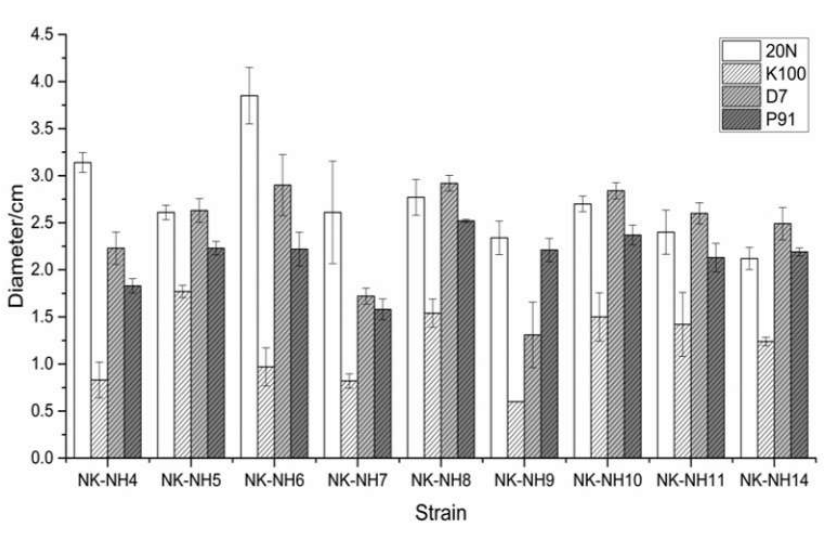

B

Figure 4. Photograph showing the inhibition of bacterial growth by biocides. (A) The colonies of nine strains grown on Remazol brilliant blue plates at $28{ }^{\circ} \mathrm{C}$ for 4 days: (a) Microbacterium sp. NK-NH4, (b) Bacillus tequilensis NK-NH5, (c) Bacillus subtilis NK-NH6, (d) Pseudomonas sp. NK-NH7, (e) Bacillus sp. NK-NH8, (f) Ochrobactrum sp. NK-NH9, (g) Bacillus megaterium NK-NH10, (h) Bacillus velezensis NK-NH11, and (i) Stenotrophomonas sp. NK-NH14. (B) The diameter of the inhibition circle was measured in centimeters. The vertical lines indicate the standard deviation of the three measurements. All bacterial isolates were cultured in three parallel tests at $28^{\circ} \mathrm{C}$ for 3 days. 


\section{Discussion}

Microorganisms play an important role in the degradation of woody artifacts [17]. Therefore, the inhibition of microbial corrosion is critical in maintaining important cultural heritage projects. Given that bacteria are the main degraders of archaeological wood under near-anaerobic conditions [18], we focused on the bacterial communities present in the water used to store the lacquer plates from an excavated 800-year-old shipwreck.

High-throughput sequencing results showed that the most abundant bacteria in the water samples were Flavobacterium, Pseudomonas, Xanthobacter, Rhizobium, Acinetobacter, and Novosphingobium. Among them, Flavobacterium and Pseudomonas were detected in all four water samples. After traditional microbial culture, isolation, purification, and 16s rRNA gene identification, Pseudomonas, Microbacterium, Bacillus, Ochrobactrum, and Achromobacter were obtained.

Pseudomonas is an obligate aerobic gram-negative genus and is common in a variety of terrestrial environments. Recently, Pseudomonas has been found in Antarctic soil and even in deep sea sediments [19]. Microbacterium is a genus of gram-positive aerobic bacteria. Studies have shown that Microbacterium may have the ability to degrade lignin [20]. Bacillus is generally an aerobic heterotrophic bacterium, and the presence of Bacillus indicates that the environment is rich in organic matter. Gontang et al. found that Bacillus licheniformis is a type of cultivable bacteria that can be found in the 0- to 500-meter intertidal zone sediments of the Western Pacific Islands $\left(7^{\circ} 30^{\prime} \mathrm{N}, 134^{\circ} 30^{\prime} \mathrm{E}\right)$ [21]. Sun et al. determined the diversity and abundance of Bacillus in South China Sea sediments, where Pseudomonas, Microbacterium, Achromobacter, and other genera are present [12]. Ochrobactrum is a genus of gram-negative bacteria with a strict respiratory metabolism that is obligate aerobic. Bao et al. isolated an Ochrobactrum sp. LJY313 from sea mud samples from the Arctic Ocean [22]. Flavobacterium is a genus of gram-negative, nonmotile and motile bacteria. Flavobacteria are found in soil and fresh water in a variety of environments [23]. Xanthobacter is an aerobic, spherical- to rod-shaped gram-negative Bacillus of unidentified genus. This genus consists of inorganic or organic nitrogen-fixing bacteria that live in moist soils and waters. Rhizobium is a genus of gram-negative, motile, nonsporulating rods. Rhizobium has nitrogen fixation abilities but has not yet been found in the ocean. The species of the genus Acinetobacter are strictly aerobic, nonfermentative, gram-negative bacilli. Acinetobacter species are widely distributed in nature and commonly occur in soil and water. They are able to survive on moist and dry surfaces and have the capacity to survive exposure to various common disinfectants. Furthermore, Acinetobacter species can grow at a broad range of temperatures, allowing them to survive in a broad array of environments [24]. Novosphingobium is a genus of gram-negative bacteria. Novosphingobium is ubiquitous in the environment, and there are traces of it in rivers, rhizospheres, surface sediments, deep underground sediments, oceans, and even polar soils. Achromobacter is a genus of gram-negative bacteria; Achromobacter species are strictly aerobic and are found in water (fresh and marine) and soils [25].

Almost all bacteria of known physiological groups can be found in marine environments. Studies have found that Xanthobacter, Novosphingobium, Pseudomonas, Microbacterium, Flavobacterium, and Bacillus appear in eutrophic lakes [26]. Bacteria, such as Pseudomonas, Flavobacterium, and Bacillus, have been reported to have extensive algae-dissolving abilities [27,28].

In fact, biological degradation is the main threat to archaeological wood [29]. It is also impossible to ignore the influence of bacteria living in the water on waterlogged archaeological wood [30]. There are indeed a number of wooden artifacts suffering from the biodegradation caused by bacteria.

According to M. D. Herraiz and V. Jurado, several types of dominant bacteria, such as Actinobacteria, Alphaproteobacteria, Gammaproteobacteria, and Acidobacteria, were isolated from the samples collected from the Tomba della Scimmia (Tomb of the Monkey) 480-470 BC near Chiusi, Italy [31]. According to C. G. Björdl, T. Nilson, and G. Daniel, the microbial decay of waterlogged archaeological wood found in Sweden was mainly caused by bacterial corrosion [32]. A similar case is also exemplified by the Xiaobaijiao shipwreck (1821-1850) in Zhejiang province [9]. Moreover, according to Y. H. Chen, bamboo slips, belonging to the Three Kingdoms period, that were excavated 
from Changsha, Hunan have suffered from degradation by seven genera of bacteria: Bacillus, Acinetobacter, Staphylococcus, Pandoraea, Novosphingobium, Cupriavidus, and Comamonas [8].

Microbial interactions also have important effects on the degradation of cellulose and lignin in wood. Studies on the biodegradation of cellulose have shown that the degradation of cellulose by a single microorganism is difficult or only weak and must rely on the combined action of two or more microorganisms [33]. Due to the synergistic effect and interdependence of different species in the microbial community, it is speculated that the interaction of microorganisms in the liquid matrix may greatly improve enzyme activity and promote the degradation of cellulose. The biodegradation of lignin under natural conditions is also the result of the combined action of many kinds of microorganisms, among which the role of fungi is the most important. For example, the high-throughput sequencing of fungi involved in our research was conducted, though the results were not published; Penicillium sp. and Fusarium sp. were the most predominant fungi. A rising number of studies on the bacterial degradation of lignin have proved that bacteria can degrade lignin in a liquid matrix and, at the same time, have a good ability to adapt and regulate the environment [34]. Bacteria degrade lignin in the primary metabolic stage and synthesize lignin-degrading enzymes in the logarithmic and stable growth stages [35]. In the degradation process, bacteria mainly denaturate lignin to a certain extent and make it a water-soluble polymer, but they seldom mineralize lignin into $\mathrm{CO}_{2}$. In addition, bacteria mainly play an indirect role in the degradation of lignin, and there are synergistic effects between bacteria and fungi in the degradation of lignin [36].

For waterlogged wooden artifacts, we suggest that some effective measures can be taken to conserve them. Most wooden remains from archaeological sites in waterlogged burial environments are found to be intact without shrinkage, despite centuries of storage. However, waterlogged wooden remains are subject to shrinkage damage, and some even lose up to $80 \%$ of their original volume when exposed to air [37]. When such objects are allowed to dry, they may collapse [38]. This is the reason why lacquer plates excavated from the Nanhai No. 1 shipwreck need to be conserved in water prior to reinforcement. Hence, it has been feasible to store the lacquer plates in sterilized distilled water or double distilled water $\left(\mathrm{ddH}_{2} \mathrm{O}\right)$, providing an environment with few microorganisms. While in storage, the water should be replaced at regular intervals. Furthermore, cold, dark and near-anaerobic conditions result in slower degradation [38]. Since the lacquer plates from the Nanhai No. 1 shipwreck involved in this research still need to be stored in water, the measure of maintaining an anaerobic environment needs to be considered. Meanwhile, other waterlogged wooden artifacts may take this method into account. In addition, the temperature used for wooden storage should be taken into consideration-waterlogged wood should be preserved at a low temperature of approximately $4{ }^{\circ} \mathrm{C}$ to inhibit bacterial growth.

In addition to controlling the preservation environment, undertaking efficient monitoring and using protective measures are imperative, as the results of the high-throughput sequencing showed that the change in bacterial communities at different sampling times was remarkable. First, the water samples used to store lacquer plates should be constantly monitored to assess whether the microbial communities change. Second, the application of efficient and low-toxicity biocides may be considered to restrain bacterial growth and mitigate biodeterioration [39]. Although the biocide susceptibility test illustrated the great capacity of biocides to chemically repress the growth of prominent bacteria, biocides can exert pressure on microbial communities, resulting in the development of biocide-resistant mechanisms or the replacement of dominant bacteria with new microbial communities, which may bring about more serious damage to cultural artifacts [2]. For example, in the French Lascaux Cave, a series of biocide treatments were applied that led to new microbial outbreaks [40]. Therefore, the application of biocides in moderation may be the optional approach. Before using biocides, however, their potential harm to humans, the environment, and to cultural relics should be taken into account, and further tests may be required to evaluate these factors.

Supplementary Materials: The following materials are available online at http:/ / www.mdpi.com/2076-3417/ 9/4/653/s1: Figure S1—the form of lacquer plates soaking in the water; Figure S2-colonies of nine strains 
grown on azure plates at $28{ }^{\circ} \mathrm{C}$ for 4 days; and Table S1-describes the effectivity of different biocides against different strains.

Author Contributions: J.P. conceived and planned the research. L.Y., Y.J. (Yin Jia), and M.W. conducted the experiment and wrote the manuscript. H.Y. and Y.J. (Ying Jing) were involved in the experiment of culturing strains. Z.L. and C.H. collected the water samples. F.Z. and M.S. provided guidance on manuscript writing. Y.C. and J.L. provided access to the sampling site and supplied the historical and environmental data of the lacquer.

Acknowledgments: We are grateful for financial support from the Fundamental Research Funds for the Central Universities, Nankai University (Grant Number 63181211) and the Fundamental Research Funds for the Central Public Research Institutes (2016-JBKY-19 and 2018-JBKY-01). We are also grateful for financial support from National College Students' innovation and entrepreneurship training program in 2017 (Program Number 201710055097). We thank other members of our lab who provided valuable and constructive suggestions.

Conflicts of Interest: The authors declare no conflict of interest.

\section{References}

1. Wang, Y.L.; Xiao, D.S. The excavation of the "Nanhai No. 1" shipwreck of the Song Dynasty in 2014. Archaeology 2016, 12, 56-83.

2. Liu, Z.; Fu, T.; Hu, C.; Shen, D.; Macchioni, N.; Sozzi, L.; Chen, Y.; Liu, J.; Tian, X.; Ge, Q. Microbial community analysis and biodeterioration of waterlogged archaeological wood from the Nanhai No. 1 shipwreck during storage. Sci. Rep. 2018, 8, 7170. [CrossRef] [PubMed]

3. Mcqueen, C.M.A.; Tamburini, D.; Łucejko, J.J.; Braovac, S.; Gambineri, F.; Modugno, F.; Colombini, M.P.; Kutzke, H. New insights into the degradation processes and influence of the conservation treatment in alum-treated wood from the Oseberg collection. Microchem. J. 2017, 132, 119-129. [CrossRef]

4. Huang, J.H.; Yang, L.; Wang, L.Q.; Yan, S.M.; Wang, W.F. The conservation of a polychrome lacquer plate in archaeology site. Wenbo 2009, 6, 292-297.

5. Yizheng Museum. The auspicial lacquer plate excavated from the Yizheng, Early Han cemetery in Yangzhou, Jiangsu. Cult. Southeast China 2007, 6, 19-22.

6. Mo, Z. The preservation and the repairing of the lacquer plate from Zhangzheng Tomb of the Early Han Dynasty. Rep. Relics China 2018, 9, 1-6.

7. Tamburini, D.; Łucejko, J.J.; Modugno, F.; Colombini, M.P. Combined pyrolysis-based techniques to evaluate the state of preservation of archaeological wood in the presence of consolidating agents. J. Anal. Appl. Pyrolysis 2016, 112, 429-441. [CrossRef]

8. Chen, Y.H. The Separation, Identification and Degradation of Lignin of the Bamboo Slips of the Three Kingdoms Period. Master's Thesis, Central South University, Changsha, China, 2009.

9. Gao, M.G.; Zhang, Q.F.; Jin, T.; Luo, P.; Li, Q.; Xu, R.L. Observation and damage assessment of microbial diseases in some wooden cultural relics from the ancient marine shipwreck, Ningbo Xiaobaijiao No. 1. Sci. Conserv. Archaeol. 2017, 29, 93-102.

10. Chen, J.C.; Huang, X.; Chen, X.L.; Chen, Z.X. Corrosion type and conservation of archaeological waterlogged wood. Mater. Rev. 2015, 29, 96-101.

11. Tamburini, D.; Łucejko, J.J.; Zborowska, M.; Modugno, F.; Prądzyński, W.; Colombini, M.P. Archaeological wood degradation at the site of Biskupin (Poland): Wet chemical analysis and evaluation of specific Py-GC/MS profiles. J. Anal. Applied Pyrolysis 2015, 115, 7-15. [CrossRef]

12. Sun, F. Diversity of bacteria isolated from the South China Sea sediments. Acta Microbiol. Sin. 2008, 48, 1578-1587.

13. Abdellaoui, R.; Gouja, H.; Sayah, A.; Neffati, M. An efficient DNA extraction method for desert Calligonum species. Biochem. Genet. 2011, 49, 695. [CrossRef] [PubMed]

14. Zhang, Q.F.; Yu, Z.L. A strain of lignin-degrading bacteria's screening and optimization of enzyme-producing condition. J. Agric. Sci. Technol. 2014, 16, 143-148.

15. Ahmad, B.; Nigar, S.; Shah, S.S.A.; Bashir, S.; Ali, J.; Yousaf, S.; Bangash, J.A. Isolation and identification of cellulose degrading bacteria from municipal waste and their screening for potential antimicrobial activity. World Appl. Sci. J. 2013, 27, 1420-1426.

16. Ji, H.W.; Zhang, L.; Liu, J.; Wang, F. Progress on analytical method for isothiazolinone derivatives used as industrial biocides. Chem. Reagents 2016, 38, 523-527. 
17. Liu, L. MicrobiaI corrosion and anti-corrosion measures for waterlogged wood objects. China Cult. Heritage Sci. Res. 2014, 4, 83-85.

18. Powell, K.L.; Pedley, S.; Daniel, G.; Corfield, M. Ultrastructural observations of microbial succession and decay of wood buried at a Bronze Age archaeological site. Int. Biodeterior. Biodegradation 2001, 47, 165-173. [CrossRef]

19. Cui, Z.; Lai, Q.; Dong, C.; Shao, Z. Biodiversity of polycyclic aromatic hydrocarbon-degrading bacteria from deep sea sediments of the Middle Atlantic Ridge. Environ. Microbiol. 2010, 10, 2138-2149. [CrossRef]

20. Li, Y.H. Screening and identification of cellulose degradation bacteria. Mod. Agric. Sci. Technol. 2012, 2, 34-35.

21. Gontang, E.A.; William, F.; Jensen, P.R. Phylogenetic diversity of gram-positive bacteria cultured from marine sediments. Appl. Environ. Microbiol. 2007, 73, 3272-3282. [CrossRef]

22. Bao, Y.C.; Jin, L.M.; Chen, J.L.; Wang, G.T.; Wang, L.L.; Quan, C.S. Optimization of fermentation conditions of Marine Bacteria Ochrobactrum sp. LJY313. Food Ind. 2017, 11, 47-49.

23. Bernardet, J.F.; Segers, P.; Vancanneyt, M.F.; Kersters, K.; Vandamme, P. Cutting a Gordian knot: Emended classification and description of the genus Flavobacterium, emended description of the family Flavobacteriaceae, and proposal of Flaviobacterium hydatis nom. nov. (basonym, Cytophaga aquatalis Strohl and Tait 1978). Int. J. Syst. Bacteriol. 1996, 46, 128-148. [CrossRef]

24. Doughari, H.J.; Ndakidemi, P.A.; Human, I.S.; Benade, S. The ecology, biology and pathogenesis of Acinetobacter spp.: An overview. Microbes Environ. 2011, 26, 101-112. [CrossRef] [PubMed]

25. Garrity, G.M.; Brenner, D.J.; Krieg, N.R.; Staley, J.T. The proteobacteria, part C: The alpha-, beta-, delta-, and Epsilonproteobacteria. In Bergey's Manual of Systematic Bacteriology; Bergey, D.H., Garrity, G.M., Brenner, D.J., Eds.; Springer: New York, NY, USA, 2005; Volume 2.

26. Zheng, Y.K.; Liu, K.; Xiong, Z.J.; Miao, C.P.; Chen, Y.W.; Li-Hua, X.U.; Zhao, L.X. Effect of large-scale planting water hyacinth on cultivable bacterial community structure in the eutrophic lake. Microbiol. China 2015, 42, $42-53$.

27. Wu, G.; Xi, Y.; Zhao, Y.J. The latest development of research on Algae-Lysing bacteria. Res. Environ. Sci. 2002, $15,43-46$.

28. Dong, L.; Yi, L.; Zheng, T. Advance in the research of marine algicidal functional bacteria and their algicidal mechanism. Adv. Earth Sci. 2013, 28, 243-252.

29. Blanchette, R.A. A review of microbial deterioration found in archaeological wood from different environments. Int. Biodeterior. Biodegrad. 2000, 46, 189-204. [CrossRef]

30. Huang, X.; Yang, T.; Wu, H.; Zhang, X.Y.; Li, J.; Zhou, X.; Xiao, L.; Zhao, K. Bacterial community structure in waterlogged bamboo slips excavated from the Laoguanshan Han Dynasty Tomb of Chengdu. J. Appl. Environ. Biol. 2018, 3, 1-9.

31. Diaz-Herraiz, M.; Jurado, V.; Cuezva, S.; Laiz, L.; Pallecchi, P.; Tiano, P.; Sanchez-Moral, S.; Saiz-Jimenez, C. The actinobacterial colonization of Etruscan paintings. Sci. Rep. 2013, 3, 1440. [CrossRef]

32. Björdal, C.G.; Nilsson, T.; Daniel, G. Microbial decay of waterlogged archaeological wood found in Sweden Applicable to archaeology and conservation. Int. Biodeterior. Biodegrad. 1999, 43, 63-73. [CrossRef]

33. Fan, Q.Q.; Liu, Y.L.; Luo, Y.T.; Fu, R. Selection of cellulose degradation microbial floras in environment and analysis of degradation capability. Sichuan Chem. Ind. 2009, 12, 48-51.

34. Song, W.Z. Biodegradation of Lignin by Composite Flora. Master's Thesis, South China University of Technology, Guangzhou, China, 2014.

35. Zhang, J.Y.; Gong, L.P.; Luo, Y.X.; Xu, W.Y.; Ling, J. Biodegradation of lignin in wheat straw by Alkaliphilic bacteria with compounded carbons. Environ. Sci. 2002, 23, 70-73. [CrossRef]

36. Kumar, L.; Rathore, V.S.; Srivastava, H.S. (14)C-[lignin]-lignocellulose biodegradation by bacteria isolated from polluted soil. Indian J. Exp. Biol. 2001, 39, 584-589. [PubMed]

37. Chen, J.; Chai, D.; Zhou, J.; Huang, X.; Chen, S. Shape recovery of collapsed archaeological wood ware with active alkali-urea treatment. J. Archaeol. Sci. 2009, 36, 434-440.

38. Helms, A.C.; Martiny, A.C.; Hofman-Bang, J.; Ahring, B.K.; Kilstrup, M. Identification of bacterial cultures from archaeological wood using molecular biological techniques. Int. Biodeterior. Biodegrad. 2004, 53, 79-88. [CrossRef] 
39. Mitchell, R.; Mcnamara, C.J. Cultural heritage microbiology. Tijdschr. Filos. 2010, 35, 917-920.

40. Martin-Sanchez, P.M.; Nováková, A.; Bastian, F.; Alabouvette, C.; Saiz-Jimenez, C. Use of biocides for the control of fungal outbreaks in subterranean environments: The case of the Lascaux Cave in France. Environ. Sci. Technol. 2012, 46, 3762. [CrossRef] 